\title{
CONSTRUCTIVIST THEORY AND A TEACHING AND LEARNING CYCLE IN ENGLISH \\ Ratna Rintaningrum
}

\begin{abstract}
Today the philosophy of constructivism has been spread through the world; and it seems that this philosophy has become the most popular in education. This might be because the concepts of this philosophy have been supported by the advance of digital technology which offers large variety of activities, in which the activities involve those required by constructivism.
\end{abstract}

Keywords: constructivism, methodology, learning cycle.

The popularity of English in the world has impacted English as Second Language worldwide. English instruction that results in competent English users is in great demand in Western and Asian countries. Undoubtedly, the users' demand will highlight differences in English Language Teaching practices. Hence, English as one of the most sought-after foreign languages to be learned has experienced perpetual development in its methodology and curricula. It occurs because approaching language learning from the perspective of the texts requires an accompanying methodology which can enable students to develop the knowledge and skills to deal with spoken and written texts in social contexts.

In attempt to accommodating such needs, language specialists and educators in English as a Second Language have been working seriously in finding the most effective methodology for implementing a text-based syllabus. Experts argued that "genre approach" is the approach that is likely to bring changes and challenges both for the users and the English educators.

The paper explores and discusses Hammond et al's proposed Systemic teaching and learning, and how Constructivist theory that is based upon Bruner's and Vygotsky's views inform the systemic teaching and learning, followed by the example. 


\section{Methodology and the Genre Approach}

Methodology refers to "the underlying approach which influences how students work with syllabus content in the classroom" (Feez \& Joice, 2004 ) and genre approach is one of the examples of the approach. The genre approach has been developed as a "visible pedagogy" which clearly identifies "what is to be learned and what is to be assessed" (Feez \& Joice, 2004). This approach is concerned with providing students with explicit knowledge about language. It values teacher-learner interaction as well as interaction between students.

The role of the teacher in this more explicit approach is to use methodologies which collaborate with the student in the learning process. Rather than standing back, the teacher intervenes where necessary in the learning process to support students as they build knowledge and skills which have been negotiated.

\section{Theories of learning}

Is it important for teachers to know theories of learning? I view that it is very important for a teacher to know theories of learning. One reason is that the theories of learning will guide the teacher in determining the goals of his teaching. In other words, this will become a fundamental base of his or her teaching. Here, Cole and Chan (1994) defined theory as a set of ideas or propositions of an abstract kind used to guide methods, select principles and guide practical decision-making.

In addition, Vigothsky cited in Bruning et al. (2004) proposed a popular concept called 'zone of proximal development'. Bruning et al. (2004) defined 'zone of proximal development' as the difference between the difficulty level of a problem that a child can cope with independently and the level that can be accomplished with adult help.

However, it seems that theories are not enough. There are still other steps after having theories. Cole and Chan (1994) described four levels of effective teaching: the first level is theoretical models. For Cole and Chan (1994), this level is on the top. This means that the first step that a teacher should do is to have the theories. The 
second level is principles. Why are principles placed after the theories? It is because principles are derived from theoretical models. To make it clearer, let us see the definition of principles. Cole and Chan (1994) defined principles as generalizations used as guidelines for action. The next is methods, and strategies and techniques are used to organize classroom practice. Hence, we can see that there is strong relationship between the four aspects, and correlation between theories and practice.

According to Cole and Chan (1994), there are several dimensions to the professional role in teaching: commitment to ethical and professional standards; perceived self-efficacy; analytical strategies and reflective cognitive style; knowledge of the content of curriculum; and high levels of literacy and numeracy.

\section{Constructivist Theory}

English as a Second Language uses Constructivist theory approach and teaches five constructions teaching model. The constructivist approach to teaching and learning is based on a combination of a subset of research within cognitive psychology and a subset of research within social psychology (Huitt, 2003).

The basic premise is that an individual learner must actively "build" knowledge and skills (Bruner, 1990 as cited in Huitt 2003) and that information exists within these built constructs rather than in the external environment (Huitt, 2003). However, all advocates of constructivism agree that it is the individual's processing of stimuli from the environment and the resulting cognitive structures, that produce adaptive behaviour, rather that the stimuli themselves (Harnard, 1982 as cited in Huitt 2003). Bruner (1990) is considered the chief theorists among the cognitive constructionists, while Vygotsky (1978) is the major theorist among the social constructionists.

\section{Vygotsky's and Bruner's theory}


The methodology applied within the genre approach is based on the work of the Russian psychologist Vygotsky (1934/1978) and the American educational psychologist Bruner (1986).

\section{Vygotsky's Theory}

The aspect of Vygotsky's theory is the idea that potential for cognitive development is limited to a certain time span which he calls the "zone of proximal development". ZPD refers to the gap between what a given learner can achieve alone, their 'potential development as determined by independent problem solving', and what they can achieve 'through problem solving under adult guidance or in collaboration with more capable peers' (Wood, D., \& Wood, H., 1996 as cited in Kristinsdottir, 2001).

The full development during the ZPD depends upon full social interaction and the more the learner takes advantages of a teacher's assistance, the broader is its “Zone of Proximal Development”. (Kritinsdottir, 2001).

For Vygotsky, language has a particular role in learning and development by acquiring a language, a learner is provided the means to think in new ways and gains a new cognitive tool for making sense of the world.

\section{A learning model based on Vygotsky's concepts of development}

Vigotsky suggests two things about language learning: "If a teacher is only concerned with what students can already do with language ie with their existing level of independent performance, then the students will never progress". "If a teacher supports students so that they move through the zone of proximal development to their potential level of performance, real learning and progress is possible" (Feez \& Joice, 1998).

The model also suggests that input alone is not enough for students to reach their potential. Vygotsky proposes that learning is collaboration between teacher and student with the teacher taking on an authoritative role similar to that of an expert supporting an apprentice. He points out that this collaboration always involves 
language in the form of a dialogue between teacher and student (Kristinsdottir, 2001).

\section{Bruner's theory}

Bruner (1960, as cited in Kristinsdottir, 2001) proposed a "spiral curriculum" concept to facilitate structuring a curriculum 'around the great issues, principles, and values that a society deems worthy of the continual concern of its members' and described the principles behind the spiral curriculum in the following way:

"I was struck by the fact that successful efforts to teach highly structured bodies of knowledge like mathematics, physical sciences, and even the field of history often took the form of metaphoric spiral in which at some simple level a set of ideas or operations were introduced in a rather intuitive way and, once mastered in that spirit, were then revisited and reconstructed in a more formal or operational way, then being connected with other knowledge, the mastery at this stage then being carried one step higher to a new level of formal or operational rigour and to a broader level of abstraction and comprehensiveness. The end stage of this process was eventual mastery of the connexity and structure of a large body of knowledge"... (pp. 3-4).

Wood, Bruner and Ross (1976, as cited in Kristinsdottir 2001) invent the term 'scaffolding' to describe tutorial interaction between a teacher and a student. The metaphor was used to explore the nature of aid provided by a teacher for students learning how to carry out a task they could not perform alone (ibid). Bruner's ideas of

spiral curriculum and scaffolding are related. A parallel has been drawn between the notion of scaffolding and ZPD theories of Vygotsky (Kristinsdottir, 2001).

\section{Four phases in the changing nature of the collaboration between teacher and student in response to learner progress:}

\section{Phase one: learner's entry level assessed by teacher}

1. In this level, teacher begins activities with students from known to unknown. It means that learning is an active process in which learners construct new ideas or concepts based upon knowledge that students have already had. 


\section{Phase two: significant contribution from teacher to support dependent contribution from learner.}

2. In this phase, teacher moves from context of culture to context of situation and asks students to look at Field, Tenor and Mode.

3. Teacher might focus on include verb and noun choices and the organization of the clauses (Paltridge, 2004).

\section{Phase 3: Diminishing contribution from teacher as learner's independent contribution increases.}

1. Teacher gives more practices to students to make sure that students understand the materials given.

2. Once students' competence increases, the teacher focuses less on input and instruction and begins to act as a facilitator for classroom activities.

3. This includes encouraging students to communicate, monitoring their performance, and providing feedback on their work.

\section{Phase 4: Scaffolding}

Independent performance with no contribution from teacher.

1. Students work independently with the text.

2. Learner performances are used for achievement assessment.

This methodology is designed to support language learning as a social process and includes the following elements: Joint consruction and Scaffolding. Through joint construction "the teacher and the student develop text together and share the responsibility for performance until the student has the knowledge and skills to perform independently and with sole responsibility”(Feez \& Joice, 1998). Scaffolding involves providing support for learners as they develop in their linguistic competence. Integral to this notion is the idea that learners are "in the position of solving a 
problem that is beyond their level of competence" (Hawkins, 1988 as cited in Paltridge 2004). At the same time, the person that is helping them is in the position of "knowing" how to perform the task. Through the scaffolded interaction, learners come to the point where they are able to perform the task, first with assistance, then independently (Hawkins, 1988 as cited in Paltridge, 2004).

\section{A Teaching and Learning Cycle}

\section{The Aim of the Teaching and Learning Cycle}

Providing support for learners as they move from building up the content of a text, through the presentation and discussion of a model of the target text, to a "joint construction" (by the teacher and learners) of a further model text (Paltridge, 2004).

The teaching and learning cycle is based on the notion of "scaffolding" (Bruner, 1975; Wood, Bruner \& Ross, 1976; Cazden, 1988 as cited in Paltridge, 2004), which draws from Vygotsky's (1978 as cited in Kristindottir, 2001) view that

higher thinking process, including language, arise as a consequence of human interaction.

Many systemic-oriented genre-based textbooks discuss a particular teaching and learning cycle that is often associated with systemic classroom activities (Paltridge, 2004). The cycle of teaching and learning activities in the genre approach consists of a number of stages which the teacher and students go through so that students gradually gain independent control of a particular text-type (Feez \& Joice, 1998).

Each of five stages of the teaching and learning cycle has a different purpose and different types of activities. The teacher may enter at any phase of the cycle, depending on the learner's stage of preparedness for the particular activity; that is, the cycle is intended to use flexibly, with teachers encouraged to enter the cycle at whatever point best meets their students' needs (Hammond et al., 1992 as cited in Paltridge, 2004). It is also possible at any time to return to activities from earlier stages of the cycle if student need further practice to progress. 


\section{Five Stages in the Teaching and Learning Cycle}

\section{Phase One: Building The Contect: Context of culture.}

1. In this stage, teacher introduces students the social context of an authentic model of the text-type being studied.

\section{Building the Context activities}

Genre: Transactional - A business letter to order goods.

1. Teacher stimulates students some questions relate to letter

For example: How many kinds of letter have they known?

Mention types of letter they have known.

In what type of genre is letter categorized?

Why?

2. Teacher writes all the answers on the board.

3. Teacher shows students the example of business letter.

Lexis: appropriate language e.g. enclosing, to cover the cost etc

1. Teacher asks students to read the letter for recognition and understanding Key words.

2. Teacher encourages students to mention appropriate language that is provided in a business letter.

Staging of the text - see the model provided

1. Teacher asks students to fold part of the letter that contains the description of the letter (introduction, body, and closing).

2. Teacher stimulates students some questions about parts of letter.

\section{Introduction of letter}

1. Teacher asks students some questions relate to introduction of letter.

For example: What do you write first when you write a letter? 
Answer: Sender Address.

What is the next part of the letter after you wrote your address?

Answer: Date when we write it.

Do you have to write the company's name or person's name you are sending a letter?

Answer: Yes. We have to write company's name, person's name and address.

2. Teacher guides students that what they mentioned above is Introduction of the business letter.

\section{Body of letter}

For example: What do you write when you order goods?

Answer: we tell exactly what we want

Is it necessary to describe goods you order in detail?

Answer: Yes. Write the description of goods, for example how many goods we need, the size of goods, and when the goods should be received.

If you enclose money, what should you write?

Answer: We should tell the amount of money we are enclosing.

\section{Closing.}

For example: What do you write when you close your writing?

Answer: We sign and print our name.

\section{Phase Two: Modelling and Deconstructing The Text Context of Situation.}

3. Students investigate the structural pattern and language features of the model.

4. Compare the model with other examples of the text-type

\section{Modelling and Deconstructing the Text activities:}

5. Lead a discussion about business letter by asking several questions (Field= participants, processes, circumstances) 


\section{Field: A business letter to order goods}

1. Participants: Generic e.g. general office staff

Individual - person writing the letter

For example: Who writes a letter?

What kind of goods does he order?

How much money does he enclose?

2. Processes: relational e.g. being

Material e.g. send, enclose

For example: What does the sender say in the letter when he orders goods?

3. Circumstances: no temporal sequence (excluding date)

Where does the sender live?

When does he write the letter?

Where is the company address?

\section{Tenor: Power relationship: Company and client}

1. Mode: Declarative

2. Polarity: Positive

3. Modulation: expressions of specific wants: 'these are to be...'

4. Politeness markers: e.g. 'please, yours truly, dear'

For example: What is the relationship between the sender and recipient of the letter?

Is the letter sound positive or negative?

Could you mention the expressions of specific wants?

Could you find out politeness markers in the letter?

\section{Mode: How the text is communicated}

1. Written text

2. Dialogic - requires a response

3. Non face to face

For example: Is the text written or spoken?

Is it monologic or dialogic? 
Why? Give reason!

Is there visual contact between the people involved in the text?

\section{Phase Three: Joint Construction of The Text}

6 Students begin to contribute to the construction of whole examples of the texttype.

7 The teacher gradually reduces the contribution to text construction, as the students move closer to being able to control the text-type independently.

(Feez \& Joice, 1998)

Joint construction activities include:

1. Students work on a rough draft using the model provided - they write a letter in group - see example given.

2. Student groups swap letters and edit each other.

3. Teacher circulates and discusses recommended changes.

4. Each student records a copy of the corrected draft.

\section{Phase Four: Independent Construction of The Text}

In this stage:

8 Students work independently with the text.

9 Learner performances are used for achievement assessment.

(Feez \& Joice, 1998)

Independent construction activities include:

1. Teacher gives the students another order detail.

2. Students write a rough draft for submission but they work on their own this time.

3. Students submit final draft (Summative)

Phase Five: Linking To Related Texts 
In this stage, students investigate how what they have learnt in this teaching/learning cycle can be related to:

1 other texts in the same or similar contexts

2 future or past cycles of teaching and learning (Feez \& Joice, 1998).

It is very important to note that the genre approach does not advocate that students mindlessly imitate the teacher. Instead it gives students the opportunity to learn to function at a level beyond that which they could learn to do on their own (Feez \& Joice, 1998).

\section{Reference List}

Bruning, R., Schraw, B., Norby, M. and Ronning, R.R., (2004), Cognitive psychology and Instruction, Fourth Edition, Pearson, New Jersey.

Cole, P.G. and Chan.L., (1994), Teaching Principles and Practice, Second Edition, Prentice Hall, New York.

Feez, S., \& Joice, H. (1998). Text-based syllabus design. NWS, AMES, Australia.

Huitt, W. (2003). Constructivism. Educational Psychology Interactive. Valdosta, GA: Valdosta State University, Retrieved April 21, 2008 from http://chiron.valdosta.edu/whuitt/col/cogsys/construct.html

Kristinsdottir, S.B., (2001), J. Bruner. Retrieved April 10, 2008 from http://starfsfolk.khi.is/solrunb/jbruner.htm_3.htm

Kristinsdottir, S.B., (2001), Lev Vygotsly. Retrieved April 10, 2008 from http://starfsfolk.khi.is/solrunb/vygotsky.htm

Paltridge, B., (2004), Genre and the language learning classroom. University of Michigan Press., USA. 